\title{
Are we teaching critical digital literacy? Grade 9 learners' practices of digital communication
}

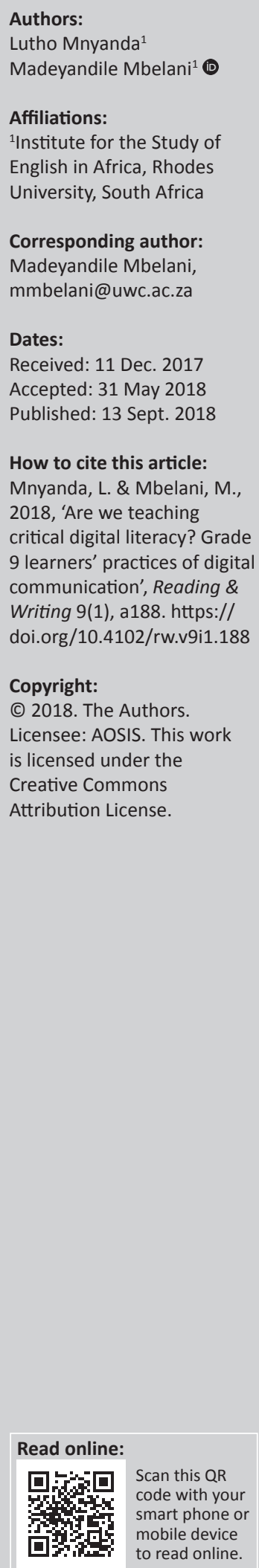

\begin{abstract}
South Africa's communication landscape has changed and is still changing because many previously disadvantaged areas have benefitted from the construction of roads, provision of electricity and installation of satellites. As a result, many previously disadvantaged learners have access to digital media in their homes. In this article, we argue that the immersion of many learners in digital media at home advances literacy achievement. Drawing on insights from cultural historical activity theory and multimodal social semiotics, we discuss the nature of learners' digital resources at home and how these resources could be meaningfully and critically used to advance literacy. Data were collected from Grade 9 learners in two King Williams Town schools in the form of questionnaires, focus group discussions, informal Facebook-Messenger conversations, one-on-one interviews with teachers and lesson observations. The analysis of data shows that many learners in this study are becoming digitally literate, irrespective of their socio-economic status or rural-urban location. However, digital literacy does not seem to be used as a base to advance literacy as advocated in the new curriculum and assessment policy statements.
\end{abstract}

\section{Introduction}

The majority of post-apartheid South African learners struggle to achieve higher order cognitive levels in literacy as reported by the Progress International Reading Literacy Skills (Howie, van Staden, Tshele, Dowse \& Zimmerman 2012). It is particularly troubling that there has been no improvement between the 2006 and 2011 PIRLS results (Howie et al. 2012). Towards the end of 2015, PIRLS tested learners with an innovation called ePIRLS, which involves an assessment of online reading, looking at how learners read, comprehend and interpret digital information. The 2012, 2013 and 2014 Annual National Assessment (ANA) diagnostic reports in Grade 9 English FAL examinations indicate that learners lack the basic skills to engage with advertisements and cartoons, namely identifying a target audience, interpreting a cartoon, as well as inferring meaning. Moreover, some South African researchers such as Leask-Smith (2009), Moodley (2013), Mbelani and Murray (2009), and Mbelani $(2007,2008,2012 a, 2012 b, 2014)$ seem to agree that the socioeconomic backgrounds of learners, lack of resources and poor pedagogical content knowledge of teachers all contribute to low literacy in South Africa. A close examination of PIRLS and ANA results and South African research on literacy (Leask-Smith 2009; Mbelani 2007; Moodley 2013) suggests a continuity of low literacy in South Africa.

However, none of the aforementioned reports and studies considered learners' out-of-school literacy, especially digital literacy. Lemphane and Prinsloo (2014) researched digital literacy practices of two groups of children in the Western Cape province of South Africa, one group from an affluent suburb family and the other group from an ordinary township family. The results of their study illuminated that both children were engaged with digital literacy, but their engagement varied significantly and pointed to substantial social inequality. Oyedemi and Mogan (2018) documented negative effects of digital inequality of many first-year university students from rural areas. There is little research that has been conducted in South Africa to investigate learners' out-of-school literacy and how English First Additional Language (EFAL) teachers could build on that out-of-school literacy to advance school literacy (Mnyanda 2017). It is for this reason that we argue that the majority of current South African learners are becoming highly proficient in out-of-school digital literacy irrespective of their socio-economic home background or rural-urban location. This article draws on insights from the cultural historical activity theory (CHAT), digital/visual/media literacy and empirical evidence gathered from a Grade 9 learners' questionnaire, focus group discussion, informal Facebook conversations, oneon-one teachers' interviews and lesson observations to support this argument. Specifically, we highlight the nature of digital resources that learners use out-of-school and how those resources are meaningfully and critically used. 


\section{Locating digital literacy within a changing landscape of literacy}

According to Kress (2010:5), '... the world of communication has changed and is still changing; the reason for that lies in a vast web of intertwined social, economic, cultural and technological changes'. These changes brought 'a new constellation of communication resources' such as the camera, television, computer and cell phones, which later became tools to create texts (Kress 2003:11). One of the visible achievements of equal access and opportunities to resources in post-apartheid South Africa is in the communication landscape. With government's focus on developing previously disadvantaged spaces, such as township and rural communities, there is construction of access roads, provision of electricity and installation of mobile phone satellites. As a result, mobile phone and Internet connectivity is fast becoming easy to access for everybody irrespective of socio-economic status, and/or rural-urban location. The majority of Grade 9 learners in this study have access to cell phones with Internet connectivity, and they use these phones for purposes of social media. Grade 9 learners are still in their early teenage years and are heavily influenced by what Kress (2010) terms the new 'communication landscape' with the Internet and the proliferation of digital media via cell phones and even smart phones.

This changing communication landscape has led to circumstances which make it possible for features of one place to be existing and active in another place as a result of globalisation (Kress 2010). Both Taylor (2012) and Perle (2010) have observed that United States (US) learners spend more than eight hours a day immersed in visual images. Mbelani (2012a) notes that this is currently the case in South Africa too, though this exposure may vary according to the urbanrural divide, and 'the density of visual communication may be lower in rural areas [and townships]' (p. 86). The effect of globalisation has led in very many places to the 'corrosion, fraying, dissolution, destruction and abandonment of older social relations, forms, structures and givens' (Kress 2010:5). As a result, social life and the nature of literacy have been redefined to accommodate this new communication landscape. It is for this reason that the New London Group coined the term 'multiliteracy' in 1996 to combine broad modes of communication and meaning making. O'Rourke (2005:1-2) stated that multiliteracy:

\footnotetext{
... broadens literacy from an emphasis on 'reading the word' to reading multi-modal texts; includes the assumption that in the process of becoming literate, students are making sense of the world and themselves in the world, assumes that literacy is also about communicating with, and understanding the communication of others; and finally assumes that part of being literate involves developing the capacity to understand the influences of cultural, social, historical and political contexts.
}

In order for an individual to be multiliterate, there is a need to develop different forms of literacies such as digital literacy, visual literacy, media literacy, computer literacy, information literacy, cine literacy and critical literacy. Buckingham (2016) warned that it is very difficult to distinguish between these forms of literacy because there is much overlap amongst them. This article leans on the principles of new literacy and specifically focuses on digital literacy which Eshet-Alkalai (2004) conceptualises as involving:

More than the mere ability to use software or operate a digital device; it includes a large variety of complex cognitive, motor, sociological, and emotional skills, which users need in order to function effectively in digital environments. The tasks required in this context include, for example, 'reading' instructions from graphical displays in user interfaces; using digital reproduction to create new, meaningful materials from existing ones; constructing knowledge from a nonlinear, hypertextual navigation; evaluating the quality and validity of information; and have a mature and realistic understanding of the 'rules' that prevail in the cyberspace. (p. 93)

This new digital literacy and other contemporary technology offer new ways of mediating and representing the world. Furthermore, we echo Buckingham's (2006) argument that new media technology can no longer be regarded simply as a matter of information or technology, especially as we seek to develop connections between children's out-of-school experiences of technology and their experiences in the classroom. This is because digital literacies are more participatory than conventional reading and writing activities. Users do not just read content but also interact with it and actively create their own content as users become active producers of content rather than passive consumers (Anderson \& Sofkova-Hashemi 2016).

\section{Research design}

This article arises from an MEd in English language teaching case study that was conducted and completed in 2016. Through an interpretive case design, the research aimed to understand meaning making of visual images as it was perceived from subjective experiences of both teachers and learners (Thomas 2010). The study presented a detailed and 'rich' account of experiences in a natural context from which interpretations can be put forward (Bassey 2000:28). This study's goals were to answer two main questions:

- What home visual literacy knowledge do Grade 9 learners bring to make sense of visual images in classrooms?

- How do teachers draw on Grade 9 learners' home visual literacy to develop school visual literacy in English first additional language (EFAL) classrooms?

To get different perspectives and understandings of this interplay, CHAT was employed as it provides a base for both description and explanation of the current situation in Grade 9 classrooms. CHAT achieves this as a result of its three core ideas. Firstly, the theory maintains that:

\footnotetext{
'... humans act collectively, learn by doing and communicate in and via their actions. Secondly, humans make, employ, and adapt tools of all kinds to learn and communicate. Thirdly, community is central to the process of making and interpreting meaning - and thus to all forms of learning, communicating, and acting ...' (Foot 2014:3).
} 
These three ideas are important in this study because they provide ways to explain the process of meaning making of visual images in Grade 9 classrooms. They highlight that digital media should not be studied in isolation, but should be considered alongside the roles of human beings and the tools they use, as well as the community in which certain actions occur. In addition, CHAT provides tools to analyse and observe how learners construct knowledge (Gedera \& Williams 2013).

This study draws on the second and third generations of the activity theory because it views 'learning as the complex result of tool mediated interactions, rather than as something opaque which happens in a student's mind' (Hardman 2005:380). There are six key elements of the activity system to describe and explain the current perceptions and practices of meaning making of digital media: subject(s), tools, object(s), rules, community and division of labour. Firstly, the subject(s) of an activity system is(are) the person or people who are directly participating in an activity and whose motives drive the activities (Kain \& Wardle 2004). The subjects in this study were Grade 9 learners and the researcher. Secondly, tools were used by the subjects in the transformation process and meaning making of digital media to achieve intended outcomes. These tools could be physical cell phones, as well as non-physical tools such as language (written and oral) skills (Kain \& Wardle 2004). Their use could enable or constrain the making of critical meaning of visual images. In essence, this study intended to explore 'by what means [... ] the subjects [were] carrying out this activity' (Mwanza 2002:85). Thirdly, for Foot (2014), an object acts as both a focal entity and a desired outcome. Similarly, Hardman (2007) has described an object as the physical or mental product that is transformed in the activity. The critical point here was finding out what tools were involved and understanding 'why that activity was taking place' (Mwanza 2002:85).

Fourthly, according to Kain and Wardle (2004), the community is the larger group that the subject is a part of and from which participants 'take their cues' (p. 12). In this study, the community members consisted of Grade 9 learners, two teachers and the researcher who all shared a common interest (Foot 2014). In order to critically understand the community, this study asks 'what was the environment in which the activity is carried out?' (Mwanza 2002:85) and aimed to explain the effect of critical meaning making of visual texts. Fifthly, the division of labour described the distribution of tasks within the activity system (Kain \& Wardle 2004). It describes both a horizontal division amongst community members and a vertical division between power- and statusholders (Hardman 2005). It was in the interest of this study to investigate 'who was responsible for what when carrying out this activity and how the roles were organised' (Mwanza 2002:85). Finally, rules provided a means to manage or minimise conflicts within the activity system. Rules are defined not only as formal and explicit dos and do nots, but also as norms, conventions and values (Kain \& Wardle 2004). In an activity system, rules drove relationships, and they both generate and constrain behaviour (Hardman 2005).
Mwanza (2002) notes the need to ask whether there are 'any cultural norms, rules and regulations governing the performance of this activity' (p. 85) in order to understand the impact of such norms on the whole system.

The context for the study was two different research sites: a rural school (RS) and a township school (TS), both in the King Williams Town district in the Eastern Cape. Convenience sampling (Latham 2007) was used in the selection of both sites because the King Williams Town district is where the first author matriculated. The participants in the study were Grade 9 learners in both schools. The sample consisted of 41 learners at the RS and 43 learners at the TS. Data were collected from questionnaires, informal Facebook-Messenger screenshots, focus group discussions with the learners, oneon-one interviews with teachers and lesson observations.

The initial plan was to observe learners at their homes, but because of the distance of the learners' homes from the school and between each other, it became impractical to cover all the students' homes. The decision to use Facebook-Messenger as a research tool was taken once the growing use of this media source was observed. Facebook is a relatively recent phenomenon and facilitates data collection by storing detailed records of its users' demographic profiles, social interactions and behaviours (Kosinski et al. 2015). However, uncertainty still exists about the most effective ways to use Facebook as a means of data collection (Wilson, Gosling \& Graham 2012). The participants were those who used and interacted with one of the authors on Facebook. Consent was requested to use screenshots of these interactions for the purposes of this study. Anonymity of the participants was ensured by obscuring original names and adding pseudonyms for learners (see screenshots). Importantly, the stimuli that these learners engaged in were not premeditated but presented as learners' online digital literacy.

\section{Learners' out-of-school digital literacy}

The availability of resources at home draws a picture of what learners were exposed to and had knowledge of. The resources in question in this study were technological devices that learners had at home. This information is presented in Table 1.

There were no major differences between the rural and urban learners as all had access to new technologies. There was also evidence that both rural and urban learners knew how to use the new technology. This was illustrated by their use of social media (WhatsApp, Facebook and Twitter) for communication, as well as their use of the Internet. In Figure 1, a TS learner described using social media for connecting with friends.

It is our contention that learners' reliance on technology for different purposes quickens their mastery of necessary skills to operate these devices. These include secondary skills (Anwaruddin 2016) that have not been formally taught but are acquired through social practice and interaction with technology. Moreover, the learners self-teach a range of 
TABLE 1: Availability of resources at home.

\begin{tabular}{|c|c|c|c|c|c|c|c|}
\hline Respondents & Technological device & Availability at home & $\%$ & Internet-enabled & Social media & Frequency on both devices & $\%$ \\
\hline \multirow[t]{2}{*}{$\mathrm{RS}$} & Cell phones & Learners have access & 100 & Yes & $\begin{array}{l}\text { - WhatsApp } \\
\text { - Facebook } \\
\text { - Twitter }\end{array}$ & $\begin{array}{l}\text { Use the Internet only a few } \\
\text { times a week. }\end{array}$ & 57 \\
\hline & Computer & Learners have access & 12 & Yes & - & & - \\
\hline TS & Cell phones & Learners have access & 100 & Yes & $\begin{array}{l}\text { - WhatsApp } \\
\text { - Facebook } \\
\text { - Twitter } \\
\text { - Instagram }\end{array}$ & $\begin{array}{l}\text { Use the Internet only a few } \\
\text { times a week }\end{array}$ & 63 \\
\hline
\end{tabular}

RS, rural school; TS, township school.

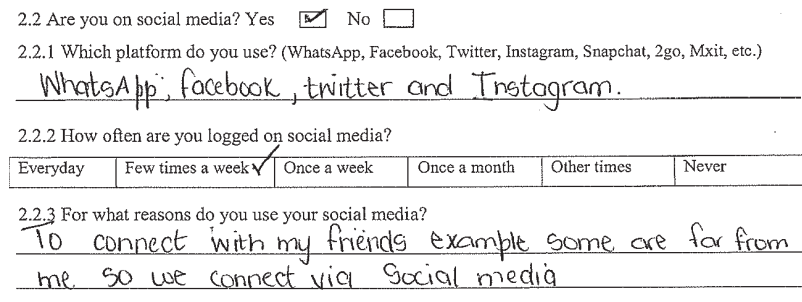

FIGURE 1: The use of social media.

Becouse the visual images ave every where tike in the row $n$ shop, school and urbans. I landerstound very ckar becouse it help -us to know how to advertise and anorlyse prctures as we look to them.

FIGURE 2: Importance of critical analysis.

digital literacy skills while using technology, and this illustrates the multiliterate ways in which learners develop. This self-teaching also demonstrates that these learners have acquired basic interpersonal communication skills in English. The learners' utterances and language use show that both RS and TS learners have a strong formal language base. Their sentence structure is easy for the reader to understand.

The development of the learners' cognitive and affective cultural engagements means that they are now being shaped and influenced by a new technological culture. The cognitive and affective development of the learners' digital knowledge is socially constructed through interaction within cyberspace (Hicks \& Turner 2013). This acquired knowledge results in new ways of understanding the world that is driven by more digital content. This is a world beyond the word. Learners are not just reading words; they are critically involved in reading the world and making connections between critical literacy and politics (Macedo \& Freire 1987). In Figure 2, an RS learner realises the influence of visual images in everyday life and the need for critical analysis.

It is not possible to talk about critical literacy today without referencing the use of technology (Hicks \& Turner 2013). It is through the use of technological devices that the minds of the learners are being developed as they engage with different people within cyberspace. This means that on the formal operational stage, these learners are highly technological, and their knowledge is invariably influenced by new forms of communication.

\section{Demonstration of digital literacy in social media via Facebook}

We argue that learners develop communication skills through digital technology. In reality, both the township and rural learners engage in social media communication and are exposed to global information. The learners are not at a disadvantage when it comes to understanding visual images used in social media. Indeed, they appear to have developed cognitively at an interesting rate as they are able to engage in current affairs discussions. For example, a conversation that one of the authors had on Facebook-Messenger with one of the RS learners about the recent US elections and Donald Trump's victory (see Figure 3): by way of providing background, the first author displays a meme ${ }^{1}$ showing Donald Moatshe, a popular South African singer with the caption, 'Congratulations Donald', on his Facebook public platform. This was after Donald Trump won the US elections in 2016. Although this was purely humorous in nature, it required the viewer of the image to know that this did not refer to Donald the South African singer but to Donald Trump. Moreover, many South Africans were rejoicing that America had a president that people had mixed feelings about, and this was tacitly juxtaposed with the South African singer, which captured this mirth.

The RS learner clearly understood the meaning and humour behind the use of this image as she was able to refer to it in her discussion. She also highlighted that other people who came across the image, did not grasp the meaning behind it. There was certainly no formal training on the use of Facebook, but there were formal language skills that learners drew on to write or communicate via Facebook. That gave learners access to the global village and enabled them to participate in discussions that affected all people globally through the use of social media. This is supported by Habib and Soliman (2015), who argued that images provide means for students to interact with phenomena across the world. Learners, therefore, have a reasoning ability that is not merely socio-economically and geographically defined. Their understanding of the visual images that are posted on social media is based on their exposure to many such images on these forums. This means that the more they use social media, the more they are able to enhance their understanding and develop their cognitive skills in interacting with different social realities.

1.Meme, mi:m/ d. an image, video, piece of text, etc., typically humorous in nature, that is copied and spread rapidly by Internet users, often with slight variations. 'English Oxford Dictionaries' 


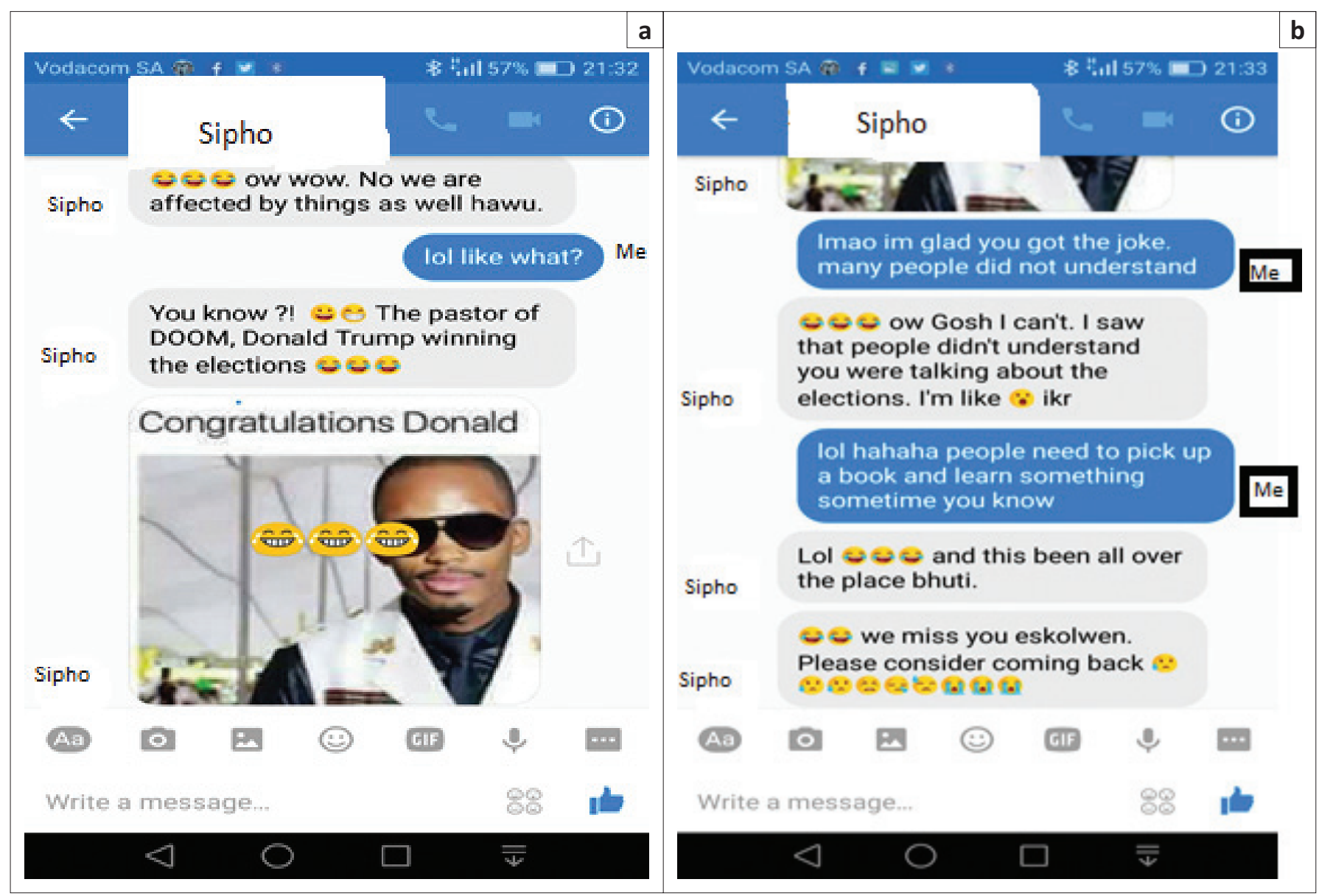

FIGURE 3: Screenshot conversation: (a) Online first discussion, and (b) online second discussion.

While understanding the context is important to grasping the meaning of visuals, and while engaging in discussions on social media is important, the language that these learners use in these spaces is also very important. Both Figures 3 and 4 show language that deviates from the norm. This is a text speech (Janks 2013) that combines both isiXhosa and English. Such expression is informal and employs a basic level of communication that all users can understand. Formal English and isiXhosa conventions on social media are seldom used, and hence, there is autonomy to move in between languages. Although it can have positive effects on the development of English for basic communication, it can prove to be a disadvantage for formal language development in the classroom.

In Figure 4, learners discuss the visual image while a participant asks for clarity because they do not understand the visual image and the message. The relaxed environment of this interaction creates a space for the learner to ask a question from peers which they might not ask of a teacher. This proved to be a worthy exercise as asking questions allows the learner to gain an understanding of the image and to engage in the discussion as well. Learners can also strengthen their ability to ask questions in the classroom for clarity on any issue that they did not understand. This illustrated that learning is a social process and the society and culture influence the learning process (Vygotsky 1978).
In keeping with sociocultural theory, learners are able to construct knowledge through interaction with more knowledgeable others (Steiner \& Mahn 1996).

Social media, which makes up a large part of communication in the learners' homes, is full of visual images. Digital literacy is further developed through engagement with social media, and the new communication landscape increases the learners' exposure to social media. Social media create a space for practising a variation of linguistic repertoires in a second language, especially a language used by young people (Anderson \& Sofkova-Hashemi 2016). Communication is one of the three social processes of social media, which also include cognition and cooperation (Trottier \& Fuchs 2014). Social media triggers cognitive processes by inviting users to interact with each other so that shared spaces of interaction are created for users to respond (Trottier \& Fuchs 2014). This means that the learners are developing cognitively through social discussions. Learners may not realise the profound impact of social media on their knowledge.

Furthermore, social media uses mixed semiotics, which means that meaning exists in a plane of techno-cultural elements, and an understanding of mixed semiotics offers insight into how these elements are formalised (Langlois 2014). Essentially, mixed semiotics offers a way to comprehend 


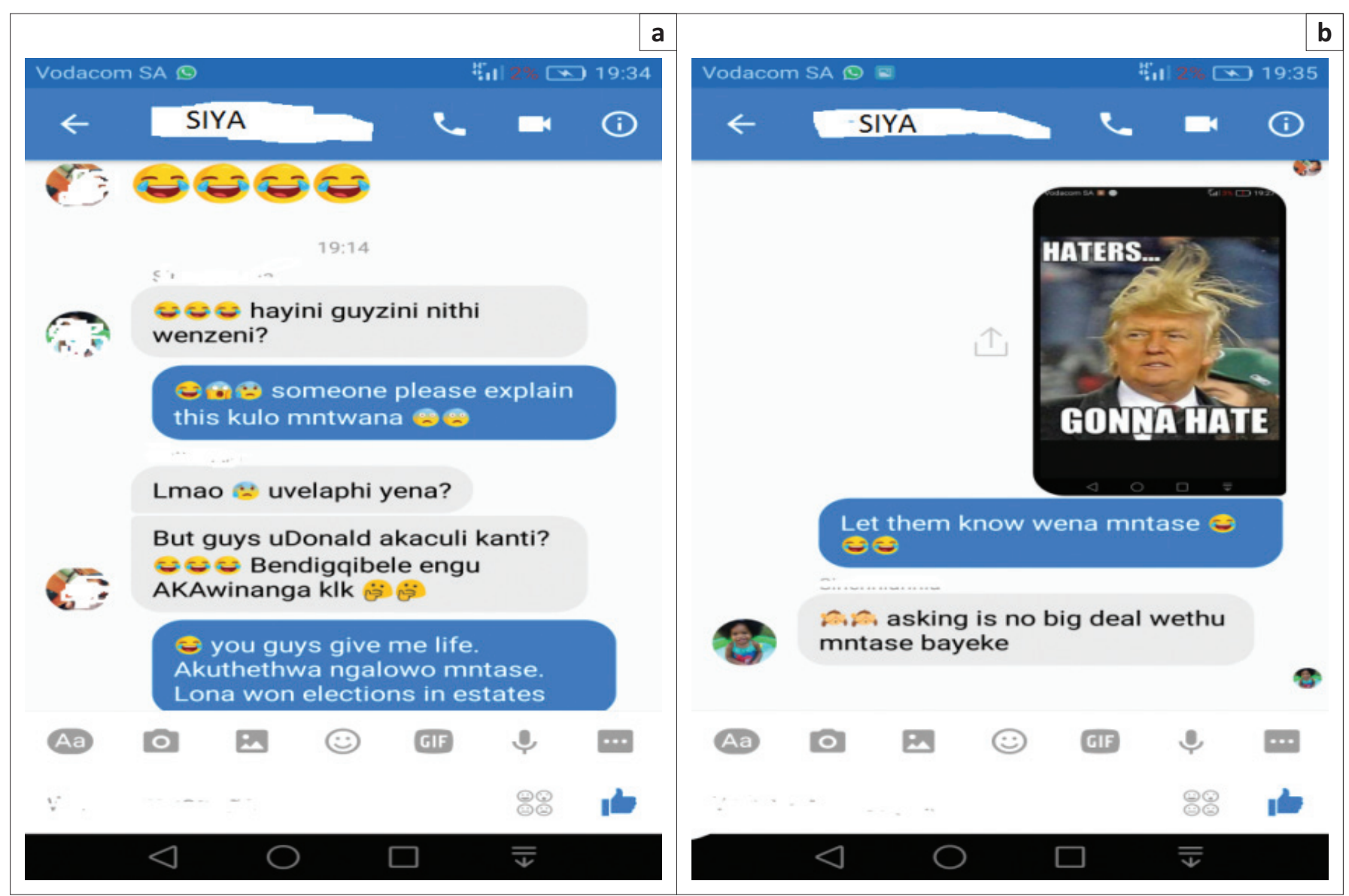

FIGURE 4: Screenshot example: (a) Online third discussion, and (b) online fourth discussion.

how meaning in social media is formed. Mixed semiotics is significant because they present visual images depicting the structuring effect of technology and software, apparent in the visual regimes of interface design and character limits (Langlois 2014). Such mixed semiotics is clearly visible in the conversation in Figure 4. The use of emoticons and shortened speech in social media are normal, and emoticons play a significant role in displaying the feelings that the person writing wants to convey. Essentially, these social media spaces give way to new forms of learning. This is what Janks (2013) found in the Mobile Literacy Project: that learners both design and consume their texts. Their technological and cultural skills come into play in interaction with other people on social media. Social media takes up so much of the learners' spare time. The skills in understanding these mixed semiotics are often not learned formally and they gradually develop over time through interaction with other friends and/or peers within cyberspace.

\section{Interplay between learners' home digital literacy and school literacy}

In the visual literacy lessons, it was observed that meaning was negotiated on a similar platform in the TS and the RS as both subjects (teachers and learners) preferred, enjoyed and viewed cartoons every day. As an illustration, Miss Dali (RS teacher) first instructed the learners to work in pairs and report back to the class, and familiarised her learners with
Thando: 'I mean, we come to school in the morning and you hear people telling each other about something that played on television.'

Researcher: 'What if some of the people did not watch it or do not have the television at home?'

Thando: *laughs* 'they listen to the other people. They have to believe even if its lies.'

FIGURE 5: Learners explaining to peers.

visual literacy basic knowledge (design and character identification) before requiring them to answer the questions on the examination paper. What was praiseworthy in Miss Dali's lesson was that she gave learners time to discuss the cartoon strip before they reported to the whole class. This was a perfect illustration of a constructivist classroom design. The class was organised into groups for both class presentation and discussion (Abuzahra, Farrah \& Zalloum 2016). Learners learned from each other and in this way they were able to teach others what they knew. Further understanding of these visual images is enabled through interaction with peers and discussing what meanings are inferred. In Figure 5 (extract 3), a TS learner explains sharing information in a focus group discussion. The learners remarked that they discussed movies and cartoons with their peers. They explained to their peers, who might not have seen the visual images to which they referred, and that was reciprocated when peers explained other visual images. The concepts of more knowledgeable peers and more knowledgeable others come into effect because the learners 
interacted with friends and family members and discussed and generated an understanding of visual images at home. This information is then brought to visual literacy lessons. As isiXhosa is the language used at home by all these learners, they discussed the visuals in their home language at home. They are therefore able to transfer information that may have been presented in English in their home language.

At another level, there was no interplay between what the teachers presented and what the learners understood of the cartoon. Learners struggled to assimilate the information that the teacher gave with what they had brought from home. One of the reasons for the poor understanding of visual literacy in the school context is that the new information is not easily assimilated or accommodated in the lessons, and this causes unresolved disequilibrium in the learners' minds (Piaget 1954). This is because the learners are unable to fit the new visual content that the teacher presents together with the existing schema brought from home. Miss Dali introduced learners to formal visual literacy in the classroom, which disrupted their equilibrium, and it was observed that both teachers have a problem with scaffolding the learners in order to enable them to be critical observers of visual texts.

In Figure 6, Miss Dali spends time describing the cartoon rather than focus on a critical analysis of the elements used. According to the first and second stages of the social constructivist model (Abuzahra et al. 2016), teachers need to allow questioning in order to bridge the gap between the home and school context. Miss Dali's preoccupation with description and knowledge means that she fails to relate the content that she may have taught in a familiar context, so that learners can relate to it and forge cognitive connections.

Contrary to what Bahrani and Soltani (2011) advocate, which is the development of critical and higher-order cognitive skills, Miss Dali spends time asking learners 'knowledge' and 'comprehension' questions related to the cartoon (Bloom 1956). These do not refine critical learning and understanding of the cartoon. Asking learners to evaluate, synthesise and analyse (higher-order questions) would require that the

Miss Dali: 'Let us start with Frame 1. I have given you a chance to discuss with your partner. What do you see? What do you think is happening? L1, let's start with you. Please give your answer in a full sentence. In frame 1 I...'

Siya: 'In frame 1 I see a cat.'

Miss Dali: 'Did you all hear him?'

Class: 'No.'

Siya: 'In frame 1 I see a cat and a man standing in front of him.'

Miss Dali: 'He said he sees a cat and a man. Uhm?'

Avu: 'I also see a cat and a man. I think the man is trying to show the cat that he is fit.'

Miss Dali: 'Okay, she said that the man is telling the cat that he is fit. Someone else? Come on guys.'

Zusiphe: 'I see the cat is sleeping and bored because of what the man is telling him.'

Miss Dali: 'You see the cat is sleeping and bored? Okay. By what the man said to him.'

Abongwe: 'I see a man very excited by his body language.'

Miss Dali: 'What is his body language? Okay. Let's move to frame 2. What can you say about frame 2 ?'

Athandwa: 'I see a man in front of the cat.'

FIGURE 6: Miss Dali Garfield's lesson. learners explain their responses and apply critical skills in their answers. This also means that these learners continue to be code breakers and text participants only according to Freebody and Luke (1990). Unfortunately, this lesson contains no critical interpretation and understanding and no application of Bloom's (1956) taxonomy levels (such as evaluating, synthesising and analysing). To employ, these levels would be to develop extended responses and higherorder thinking skills using questions with 'why' and 'what if' (Habib \& Soliman 2015). This lesson provided a perfect chance for strategic scaffolding (Anghileri 2006); the teacher could provide questions and strategies for the learners to tackle the meanings of the cartoon themselves.

Miss Dali (see Figure 7) practises a scaffolding strategy when she explains the learners' responses and answers her own questions without realising she is doing so. Unfortunately, this means that little critical thought is required from the learners. Interestingly, she asked an important question on the identification of one of the characters, but is later distracted and does not return to it. One of the learners said they watched this cartoon on television; however, some learners who do not watch the same cartoon may not have the same understanding of the characters. An important higher-order question is identified when she asks the learners to think about the cartoon that they watch from home alongside the one that is on paper. This allows for interplay between home and school literacy and taps into prior knowledge that the learners bring from home to the classroom. However, this is not fully realised as her focus shifts from her question and she does not return to it later. This means that the teacher had the opportunity to allow the interplay with prior knowledge in her lesson, but does not capitalise on it. It is worth noting that she moves the response of one learner (Bonga) from basic interpersonal communication skills (BICS) to cognitive academic language proficiency (CALP) (Cummins 1991), that is, from everyday

\footnotetext{
Miss Dali: 'So these two characters are different because the man is smiling but the cat is bored. But how do we tell that the cat is bored?'

Bonga: 'Because the cat is just looking at the man, and is thinking.'

Miss Dali: 'Yes thank you. We see from the bubble next to the cat that the cat is not actually saying this but is thinking it. Great! But who is this cat? Do we know who this cat is?'

Class: 'Yes.'

Miss Dali: 'Who?'

Class: 'Garfield.'

Miss Dali: 'Who is the man?'

Class: *mumbling*

Miss Dali: 'Do we not know theman's name? But how do you know that the cat is Garfield? What if Garfield is the man's name?'

Class: *laughs* 'No ma'am the cat is Garfield.'

Sam: 'This is a Popeye that plays on tv ma'am. We know this cat.'

Miss Dali: 'So you have seen the cat on tv before?'

Class: 'Yes ma'am.'

Miss Dali: 'Okay. Is the cat always like this here is the cartoon as it is on TV?'

Thando: 'Yes, the cat is very lazy and does not listen to the man.'

Class: 'And very fat.'

Miss Dali: 'Okay. So this cartoon is the same as what plays on TV?'

Class: 'Yes.'

Miss Dali: 'What do you think was done differently from the television and what you are seeing on the picture? Think about what we discussed yesterday.
}

FIGURE 7: Miss Dali Garfield's lesson. 
Miss May: 'Now that we all understand, do you still say Hagar is really horrible?' 'Or something bad did really happen?'

'Is it okay that he left the poor woman alone with the kids when he was encouraging for them to come?'

'It would make anyone angry, right?'

FIGURE 8: Miss May's comment on Hagar lesson.

language to academic formal language. This is important as it develops formal skills in the classroom.

On the contrary, Miss May (a TS teacher) projected her feelings towards the meaning of the cartoon rather than allowing the learners to come up with their own meanings. Learners were unable to share their feelings as to whether they liked or disliked a particular character because the teacher asked a loaded questions (see Figure 8). Unconsciously, Miss May informs the learners what conclusions to draw from the cartoon, thereby imposing her own thoughts on the Hagar character. In this case, learner-centred pedagogy would be desirable in order to engage learners' thinking as well as their beliefs. Miss May needed to divide labour in such a way that learners voiced their opinions.

Learners' home digital literacy certainly did not transfer effectively in both classrooms. The teachers found it challenging to teach visual literacy. Teachers went through the redesign cycle (Janks 2010) using their existing schemata in presenting their own lessons on visual literacy. Teachers received a design (a cartoon image designed from the perspective of the cartoonist), deconstructed the cartoon (unpacked meaning) and redesigned the cartoon (specifically to suit the needs of the classroom or the object of the lesson according to CHAT). The processes of design and redesign directly impacted the difference in interpretation. A person can understand from his or her own point of view and through their existing schema and past experiences unique to them (Baker 2015).

\section{Ethical consideration}

This study demonstrated an awareness of ethical responsibilities and a commitment to ethical research processes, with ethical clearance approved by the committee of Rhodes University (G11M3009).

\section{Conclusion}

The study yielded a number of findings. Learners' digital visual literacy skills are far ahead of those of the teachers, and teachers were sometimes not able to capitalise on these visual skills. Learners develop critical literacy through interaction on the Internet (Hicks \& Turner 2013). The use of technology also includes reading and writing, albeit digital; the research seems to indicate that there is not a low reading culture, but the medium for reading had shifted considerably to be digital. Learners developed communication skills through digital technology. The availability of technological resources to both rural and urban learners is contrary to the belief that learners in the rural Eastern Cape struggle because they lack access to new developments (Wright 2012). Learners bring knowledge from the Internet to the classroom because they interact and communicate through text speech and messages online. One of the main findings of the study is that learners have the potential to self-teach meaning production and meaning consumption.

The second main finding of the study is that teachers experience difficulty in encouraging the interplay between the learners' out-of-school digital literacy and formal school literacy, which calls for intensive development of both inservice and pre-service teachers in digital literacy. Teachers could then be at an advantage because they would no longer have to explain the context which certain visual images draw on in their teaching, but to advance literacy in general. The objective of the teacher is to critically develop learners from what they know to the unknown through the zone of proximal development. However, the main limitation of this study is that these findings cannot be generalised to all learners because there are learners who do not have smart phones. In addition, some learners live in South African communities that still do not have electricity and Internet connectivity.

Moving forward to more critical understanding and learning of digital literacy, the following questions are suggested for further research:

- How can social media be incorporated in digital literacy lessons to develop language and literacy?

- How best can in-service teachers be provided with digital literacy professional development so they can improve practice, understanding and implementing new ways of thinking?

\section{Acknowledgements}

The authors would like to acknowledge The National Research Foundation (NRF) (Unique Grant Number: 94137) for financially supporting part of this project. They would also like to acknowledge the insights from Prof. Monica Hendricks, Prof. Rajendra Chetty and Dr Peter Pluddemann.

\section{Competing interests}

The authors declare that they have no financial or personal relationships which may have inappropriately influenced them in writing this article.

\section{Authors' contributions}

L.M. conceptualised the study, collected and analysed data, and wrote the manuscript. M.M. conceptualised the study, analysed data and wrote the manuscript.

\section{References}

Abuzahra, N., Farrah, M.A. \& Zalloum, S., 2016, 'Using cartoons in language classrooms from a constructivist point of view', Arab World English Journal (AWEJ) 10(1), 229-245. https://doi.org/10.2139/ssrn.2822995 
Anderson, P. \& Sofkova-Hashemi, S., 2016, 'Screen-based literacy practices in Swedish primary schools', Nordic Journal of Digital Literacy 11(2), 83-100. https://doi. primary schools', Nordic Journal of Digital
org/10.18261/issn.1891-943×2016-02-01

Anghileri, J., 2006, 'Scaffolding practices that enhance mathematics learning', Journal of Mathematics Teacher Education 9, 33-52. https://doi.org/10.1007/210857006-9005-9

Anwaruddin, S.M., 2016, "Why critical literacy should turn to "the effective turn" Making a case for critical literacy', Studies in Cultural Politics of Education 37(3), 381-396.

Bahrani, T. \& Soltani, R., 2011, 'The pedagogical values of cartoons', Research in Human and Social Sciences 1(4), 23-34.

Baker, L., 2015, 'How many words is a picture worth? Integrating visual literacy in language learning with photographs', English Teaching Forum 53(4), 2-13.

Bassey, M., 2000, Case study research in educational settings, Open University Press, Buckingham.

Bloom, B.S., 1956, Taxonomy of educational objectives handbook 1: The cognitive domain, David McKay Co Inc., New York.

Buckingham, D., 2016, 'Defining digital literacy: What do young people need to know about digital media?', Nordic Journal of Digital Literacy, pp. 21-34. ISSN online: 1891-943X.

Cummins, J., 1991, 'Language development and academic learning', in L. Malave \& G. Duquette (eds.), Language culture and cognition, Multilingual matters, Clevedon.

Eshet-Alkalai, Y., 2004, 'Digital literacy: A conceptual framework for survival skills in the digital era', Journal of Educational Multimedia and Hypermedia 13(1), 93-106.

Foot, K., 2014, Cultural-historical activity theory: Exploring a theory to inform practice and research, University of Washington, Seattle, WA.

Freebody, P. \& Luke, A., 1990, 'Literacy programs: Debates and demands in cultural contexts', Prospect: Australian Journal of TESOL 5(7), 7-16.

Gedera, D.S.P. \& Williams, P.J., 2013, 'The use of learning technologies to facilitate engagement in an online course', International Journal of Information Technology and Computer Science (IJITCS) 10(21), 23-31.

Habib, K. \& Soliman, T., 2015, 'Cartoons' effect in changing children mental response and behaviour', Open Journal for Social Sciences 3, 248-264. https://doi. org/10.4236/jss.2015.39033

Hardman, J., 2005, 'Activity theory as a potential framework for technology research in an unequal terrain', South African Journal of Higher Education 19(2), 378-392.

Hardman, J., 2007, 'An activity theory approach to surfacing the pedagogical object in a primary school mathematics classroom', Critical Social Studies 1(1), 1-12.

Hicks, T. \& Turner, K.H., 2013, 'No longer a luxury: Digital literacy can't wait', English Journal 102(6), 58-65.

Howie, S.J., van Staden, S., Tshele, M. Dowse, C. \& Zimmerman, L., 2012, PIRLS 2011 South African children's reading literacy achievement, Centre for Evaluation and Assessment, University of Pretoria, Pretoria. ISBN978-1-77592-023-6.

Janks, H., 2010, Literacy and power, Routledge, New York.

Janks, H., 2013, 'Globalisation, diversity, and education: A South African perspective', The Educational Forum 78(1), 8-25. https://doi.org/10.1080/00131725.2014.85 0981

Kain, D. \& Wardle, E., 2004, Activity theory: An introduction for the writing classroom, viewed 04 May 2010 from http://www.academia.edu/493321/Activity_Theory An_Introduction_for_the_Writing_Classroom

Kosinski, M., Matz, S.C., Gosling, S.D., Popov, V. \& Stillwell, D., 2015, 'Facebook as a research tool for the social sciences: Opportunities, challenges, ethical considerations, and practical guidelines', American Psychology 70(6), 543-556. https://doi.org/10.1037/a0039210

Kress, G., 2003, Literacy in the new media age, Routledge, London.

Kress, G., 2010, Multimodality: A social semiotic approach to contemporary communication, Routledge, London.

Langlois, G., 2014, Meaning in the age of social media, Palgrave Macmillan, New York.

Latham, B., 2007, Sampling: What is it? Quantitative research methods, viewed 16 February 2016, from https://docplayer.net/20989579-Sampling-what-is-itquantitative-research-methods-engl-5377-spring-2007.html
Leask-Smith, L., 2009, 'A picture's worth a thousand words: A case study of grade 10 English language educators teaching visual literacy', Unpublished master's thesis, Rhodes University.

Lemphane, P. \& Prinsloo, M., 2014, 'Children's digital literacy practices in unequal South African settings', Journal of Multilingual and Multicultural Development 35(7), 738-753. https://doi.org/10.1080/01434632.2014.908894

Macedo, D. \& Freire, P., 1987, Literacy: reading the word and the world, Greenwood Press, Praeger, United Kingdom.

Mbelani, M. \& Murray, S., 2009, 'Seeing is natural, but viewing is not: Teaching visual literacy in a rural classroom', Education as Change 13(1), 53-65. https://doi.org/1 $0.1080 / 01434632.2014 .908894$

Mbelani, M., 2007, 'Making visual literacy meaningful in a rural context: An action research case study', Unpublished master's thesis, Rhodes University, Grahamstown.

Mbelani, M., 2008, 'Winds of change in teacher's classroom assessment practice: A self-critical reflection on teaching and learning of visual literacy in a rural Eastern Cape High School', English Teaching: Practice and Critique 7(3), 100-114.

Mbelani, M., 2012a, 'Visual literacy: Experiences and reflections from rural schools', in L. Wright (ed.), South Africa's education crisis, pp. 86-99, NISC, Grahamstown.

Mbelani, M., 2012b, 'Surfacing opportunities taken and missed in teaching cartoons in English FAL classrooms', in R. Osman \& H. Venkat (ed.), Research-led teacher education, pp. 88-108, Pearson, Cape Town.

Mbelani, M., 2014, 'An investigation into the development of knowledge and strategies for the teaching of visual literacy in under-resourced Eastern Cape schools', Unpublished PhD thesis, Rhodes University, Grahamstown.

Mnyanda, L., 2017, 'Investigating the interplay between Grade 9 learners' home visual literacy knowledge and their development of school visual literacy in English First Additional Language classrooms', Unpublished MEd thesis, Rhodes University, Grahamstown.

Moodley, V., 2013, 'In-service teacher education: Asking questions for higher order thinking in visual literacy', South African Journal of Education 33(2), 1-18.

Mwanza, D., 2002, 'Conceptualising work activity for CAL systems design', Journal of Computer Assisted Learning 18, 84-92. https://doi.org/10.1046/j.02664909.2001.00214.x

O'Rourke, M., 2005, Multiliteracies for 21st century schools, Australian National Schools Network, Faculty of Education, University of Technology, Sydney.

Oyedemi, T. \& Mogan, S., 2018, 'The digitally disadvantaged: Access to digital communication technologies among first year students at a rural South African University', Africa Education Review 15(1), 175-191. https://doi.org/10.1080/18 146627.2016.1264866

Perle, L., 2010, When kids spend so much time-consuming media, whose messages are they absorbing?, viewed 20 October 2013, from http://www.commonsensemedia. org/advice-for-parents/side-effects-media

Piaget, J., 1954, The construction of reality in the child, Basic Books, New York.

Steiner, V.J. \& Mahn, H., 1996, 'Socio-cultural approaches to learning and development: A Vygotskian framework', Educational Psychologist 31(3/4), 191-206. https://doi. org/10.1080/00461520.1996.9653266

Taylor, J., 2012, Children's immersion in technology is shocking, viewed 20 October 2013, from http://huffingtonpost.com/dr-jim-taylor/childrens-immersion-inte_b_1871896

Thomas, P.Y., 2010, 'Towards developing a web-based blended learning environment at the University of Botswana', Unpublished thesis, University of South Africa, Pretoria, viewed 20 February 2016 from http://hdl.handle.net/10500/4245

Trottier, D. \& Fuchs, C. (eds.), 2014, Social media, politics and the state. Protests, revolutions, riots, crime and policing in the age of Facebook, Twitter and YouTube, Routledge, New York. ISBN 978-0-415-74909-1

Vygotsky, L.S., 1978, Mind in society: The development of higher psychological processes, Harvard University Press, Cambridge, MA.

Wilson, R.E., Gosling, S.D. \& Graham, L.T., 2012, 'A review of Facebook research in the social sciences', Perspectives on Psychological Science 7(3), 203-220. https://doi. Social sciences', Perspectives on Psych
org/10.1177/1745691612442904

Wright, L., 2012, South Africa's education crisis: Views from The Eastern Cape, NISC, Grahamstown. 